Title: Modern Romanization of Russian Toponyms per UN Technical Reference: Phonological and

\title{
Orthographic Analysis
}

Ivan Vladimirovich Zots*

*Corresponding author: ivanzots @ mail.ru. Telephone: +7-977-265-79-74. Staroalekseevskaya Street, 14/1, Apartment 6, Moscow 129626, Russian Federation.

\begin{abstract}
The paper investigates the issues of transliteration of Russian toponyms in a city environment and studies the efficiency of the Technical Reference Manual for the Standardization of Geographical Names published by the United Nations group of experts. The paper demonstrates the feasibility of the UN and Russian official transliteration standards and compares the suggested theoretical models with the practical applications found on the street signs, labels, maps, and other sources of navigation. The author presents a comprehensive account of practical transcription methods used in Moscow and offers a solution to a number of issues and discrepancies between popular transliteration models and their real-life application.
\end{abstract}

\section{Keywords}

Romanization, urbanonyms, geographical names, practical transcription, city navigation.

This research did not receive any specific grant from funding agencies in the public, commercial, or not-for-profit sectors. 


\section{Modern Romanization of Russian Toponyms per UN Technical Reference: Phonological and}

\section{Orthographic Analysis}

\subsection{Introduction}

\subsection{Research Background}

The growing rate of globalization in the modern world and the ever-increasing volume of crosscultural communication make the accurate portrayal of multilingual landscapes in a contemporary megapolis environment a pressing linguistic matter. As such, development of an adequate practical transcription system is an important issue for further advancement of multicultural, multilingual, and inclusive cities.

The past several years saw a surge of interest in transliteration of Russian toponyms and navigational information in a public setting, such as metro stations, places of tourist attraction, popular landmarks, and other areas with a high visitor traffic. The most recent and notable efforts towards detailed and thorough transliteration of urban messages include the recent FIFA 2018 championship held in Moscow. The event brought about conferences and scientific publications related to the problems of precise, easily-understood transliterated texts and the ways of their presentation to the general audience without the prior knowledge of the Russian language or Cyrillic alphabet (Presidential Library, 2018).

Due to the increased popularity of studies concerning linguistic landscape, extensive research has been performed on optimal transliteration practices in general and the usage of transliteration for navigational messages in particular, with special attention paid to the use of the English language alongside of Russian. The choice in favor of English as a basis of Romanization in Russia is made in light of several considerations. One of the more important factors is the popularity of English as a second language (Ethnologue: Languages of the World, 2019). A number of Russian studies highlight the methods of describing the linguistic landscape to characterize the quickly changing state of the language (Kirilina, 2013). Namely, transliteration and bilingualism in navigational signs are viewed as an attribute of language competition and play an important role in studying the linguistic landscape of a given environment. Another study defines the notions of 'linguistic landscape' and 'city texts' through a survey drawn upon materials collected in the city of Ufa. The author describes a sociolinguistic experiment with over 100 participants, including students and professors of Bashkir State University, and comes to a conclusion that polycoded 
texts (containing elements of both Russian and English) evoke a generally positive reaction among respondents. According to the received comments, such messages signify the global importance of the environment where they are used (Peshkova, 2016). It is worth noting that, for speakers of languages with writing systems other than the Latin alphabet, the English language and script represent modernity, technological advance, and internationalization, and are widely employed in identity construction (Rivlina, 2016).

However, to the author's knowledge, very few publications can be found that discuss the issue of practical implementation of proposed Romanization solutions and the disconnect between theoretical models and the real-life approaches. For instance, most of the previous studies do not take into account the traditional, long-established ways of conveying certain names or combinations of letters and sounds in the Russian urban environment. Studies on toponymy do not often aspire to analyze the bulk of names in a particular city on a case by case basis. There have been attempts to introduce streamlined systems for the Romanization of Cyrillic languages, and some of these attempts attracted attention and were endorsed by the United Nations (UNGEGN 2013), the USA, and the UK (NGA 2014), including the System for the Romanization of Bulgarian (Ivanov, 2017). But an urgent need remains for a more hands-on study that takes into account the already established traditions of Romanization of Russian Cyrillic, their application in major Russian cities, and the possible challenges that English speakers face when trying to correlate a written Romanized toponym and its pronunciation by a Russian speaker.

\subsection{Toponymy and City Navigation}

The need for a toponymic study is substantiated by a theoretical approach in cultural geography that views the general geographical structure of any given city as a sum of its distinguishing signs and symbols acting as its spatial-generating components. Thus, a linguistic landscape of a megapolis is formed by acts of communication between its inhabitants, their use of language, and engagement with manifestations of city text, including navigational messages (Zamyatin, 2006). This approach establishes a firm link between navigational signs (represented by maps, street markers, billboards, and so on containing navigational information, often in bilingual format) and the formation of a linguistic landscape within a city that supports a homogenous multilingual cultural environment (Vikulova, 2014). Creation of such an environment - a 
public space where an area with one dominant language (Russian, in the case of this paper) is changed by an outside influence of other global languages (such as English) — is the primary objective of research behind this paper, and an attempt is made to view how the combination of two languages in city texts can be achieved in the most optimal fashion to ensure error-free communication between native Russian speakers and foreigners. The practical side of the research and analyzed data are further described in section 2.0 below.

The navigational landscape of Moscow undergoes constant evolution under the supervision of the Russian capital's Department of Transportation and Development of the Road Transport Infrastructure (Bondar, Glukhov, \& Goncharova, 2013). According to the overview published on the web-site of the Mayor's Office of Moscow, the reference concepts of the overall navigational architecture are described in the design document 'The Concept of the Unified Moscow City Navigation System,' initially published in 2013 and available for the general public on the Internet (Moscow Mayor official website, 2020). The website claims that ' $<$ the team working on the unified system of transport navigation $>$ includes graphical and industrial designers, cartographers, analysts, editors and managers. Both Russian and international experts are continuously involved.' ${ }^{1}$ One of the focal points of the city navigation emphasized in this paper is the standard of transliteration chosen for navigational texts. The aforementioned design document lists the official standard GOST 7.79-2000 as its guideline for transliteration (Interstate Council for Standardization, Metrology and Certification, 2002). The said standard is based on an older document GOST 16876-71 approved in 1981 (USSR State Committee on Standards, 1981). However, the transliteration model suggested in GOST 7.79-2000 is intended for general use and doesn't take into account specific problems and challenges presented by navigational texts. The said model was not originally designed for use with toponymy in mind.

Another document that was based on the aforementioned GOST 16876-71 and used as a basis of transliteration for a multitude of global languages is the Technical Reference manual for the standardization of geographical names published by the United Nations in 2007 (United Nations Group of Experts on

\footnotetext{
1 ‘<В команду по разработке единой системы транспортной навигации> входят графические и промышленные дизайнеры, картографы, аналитики, редакторы и менеджеры. К работе над проектом постоянно привлекаются российские и мировые эксперты' [https://www.mos.ru/city/projects/design/] (translated by the author of this article)
} 
Geographical Names, 2007). Drawing upon GOST 16876-71, the Technical Reference manual gives recommendations on Romanization of the Russian language explicitly for geographical purposes. This document remains the sole system of Russian Romanization built and intended for use with geographical names. As such, the United Nations system remains high on the agenda to this day. Since the material in the United Nations manual closely coincides with the content of the modern GOST 7.79-2000, and in many instances the GOST 7.79-2000 standard mirrors the UN's suggestions, it is feasible to provide further analysis of the Technical Reference manual and compare its suggested rules for Russian and the way they are currently implemented in Moscow and other Russian cities for navigational purposes. Namely, the paper continues to explore the bilingual texts on city signs, translations of street names, objects of cultural and historical value, names of metro stations, and other city landscape messages, collectively referred to as 'urbanonyms.'

Additionally, it is important to identify the disjunction between the system and methods currently applied in practice, and especially crucial to explain the basis behind such a disjunction. The paper identifies the most problematic examples of transliteration and proposes new approaches to convey certain letters of the Cyrillic alphabet based on extensive linguistic and sociolinguistic research.

\subsection{Materials and methods}

Following the principles of the UN Technical Reference in combination with currently established practical approaches, a system of practical transcription can be devised with a non-specialist in mind. Such a system is intended to be used for assisted city navigation purposes, where an English speaker without any prior knowledge of Cyrillic interacts with Russian speakers and Russian navigational texts to find their way in a Russian megapolis. For a system of that kind, it is less of a priority to ensure reversibility of transliteration, although reversibility can also be achieved through special means, such as introduction of auxiliary signs for specialists (e.g., interpuncts, vertical bars, diacritics) (Ivanov, 2017). Moreover, transliteration standards aren't usually well-known to casual users of any given language outside of the circle of experts, and their implementation is rarely controlled by the authorities or taught as part of education (Androutsopoulos, 2012). This leads the author to believe that, if a transliteration system such as UN's is to be used in real-life environment characterized by certain deeply-rooted practices and traditions of 
Romanization, it should be adapted to consider the needs of its end users and, most importantly, fitness for the practical task of ensuring safe navigation. To accomplish the correct and understandable conveyance of names of cultural importance, the paper relies on the principle of 3T - Translation, Transcription, Transliteration - developed specifically to take into account traditionally established ways of conveying culturally-relevant names and phonetic idiosyncrasies of lesser known toponyms (Souleimanova \& Kholodova, 2014). To expand on this point, it is possible to subdivide the overall volume of Romanized texts, such as street names, into distinct categories. For example, a small subset of names has significant cultural value and international recognition, such as the names of the best-known tourist attractions and central objects of city toponymy, like Красная площадь - Red Square in Moscow. It is reasonable to translate such names literally, because the international community is generally aware of them through dictionary entries, history books, news channels, tour guides, cultural contacts, etc. To Romanize the rest of the names that do not have a comparable degree of recognition, it is important to combine the means of transcription and transliteration and produce a variant that resembles the original in both writing and pronunciation as closely as possible.

Application of the $3 \mathrm{~T}$ principle is recommended through the method of iterative filtration which was implemented by the author during the work on the corpus of Moscow street names. The first step of iterative filtration is exclusion of names that do not pose a particular problem for Romanization, such as names consisting entirely of letters that all transliteration systems for a given language agree on (examples of such letters in Russian include $A, M$, Д, etc., as itemized below). The next step of the process is identification of each problematic letter that is conveyed differently depending on the system in place (see examples from the UN's Technical Reference manual in section 3.0). A prominent and common sign of a problematic letter is difference between its portrayal in an officially accepted transliteration system of a country or a city and the way it's written on actual maps and navigational signs throughout the country/city. For instance, certain combinations of Russian letters, such as $-И И ̆$ at the end of an urbanonym, have been noticed to feature up to six different variants of transliteration in navigational texts, including $-I I,-I Y,-Y Y,-Y,-Y I,-Y J$. Names containing such letters or combinations of letters are filtered out from the corpus and reviewed on a case by case basis. Every iteration focuses on a specific problem (for instance, differences in representing the 
Russian letter $\Gamma$ and its corresponding sounds) and applies proposed principles of Romanization to suggest a way of circumventing the problem. The next iteration focuses on the names that either exhibit an entirely new problem (for instance, names with the letter $\ddot{E}$ ) or combine the problem from the first step and the next identified issue (such as names containing both $\Gamma$ and $\ddot{E}$ ). As such, every new step iterates upon the previous one and increases the complexity of the analysis by one level at a time. Iterations continue until there are no more names left in the corpus for analysis. This allows the researcher to organize the new dictionary of Romanized names in a logical and systematic manner (Souleimanova \& Zots, 2019).

There is a number of letters in the Russian alphabet that have long-established equivalents in many transliteration systems due to a heavy resemblance between them and corresponding letters of the Latin alphabet, as well as similarities between sounds in Russian and English represented by such letters. Among them are the Russian $A, Б, B, Д, 3, И, K, Л, M, H, \Pi, P, C, У, \Phi$. Urbanonyms consisting entirely of these letters rarely allow for variations in writing, and most of the maps and street signs in Moscow and other Russian cities convey them in a similar manner. But when it comes to Russian palatalized and hushing sounds, most transliteration systems offer significantly different approaches.

The research is based on a linguistic analysis of 3029 street names of Moscow, 2065 street names of Saint Petersburg, and 275 original photographs with the most current samples of street signs, navigational information, metro station names, cultural object names, and their respective Romanizations, taken by the author in Moscow and Saint Petersburg in the period from 2015 to 2020. Examples of collected photographs and documented street names are provided in the section 3.0 below.

The remainder of the paper is organized into sections dedicated to a particular letter of interest. A detailed analysis of the suggestions in the UN's Technical Reference manual for variants that might cause ambiguity and miscommunication is offered below. For the ease of comparison, the paper uses the International Phonetic Alphabet for sound representation (International Phonetic Association, 2015).

\subsection{Detailed Analysis of Individual Letters}

\subsection{Romanization of Russian $\Gamma$ as $G$}

Transliteration of the letter $\Gamma$ in English has been a subject of debates for over a century, with arguments both for and against a universal approach to its representation in literary pieces and, more 
importantly, geographical names. Noting the variety of sounds represented by this letter in Russian, in 1890 Charles E. Groves suggested using a 'rational' approach to represent it, which involves letters or groups of letters 'which have as nearly as may be the same sound as the original,' as opposed to an 'empirical' approach, in which 'little to no account is taken of the sound of the letters in the foreign language' (Groves, 1890). To convey the Russian letter $\Gamma$ and its corresponding sounds, the Technical Reference manual suggests to use the English letter $G$ as a universal equivalent. But in different contexts of the English language this letter can represent two different phonemes: a sound $[\mathrm{g}]$ and an affricate [d] $]$. This means that to convey the sounds represented by the Russian letter $\Gamma$ one has to consider the phonetic patterns associated with the English $G$. When positioned before the English back vowels [a], [p], [o], [u], [च] (the close Russian equivalents of which are the back vowels [o], [u], and the mid vowel [a]), the letter $G$ normally corresponds to the sound [g] (for instance, улица Авангардная - Avangardnaya Ulitsa, улица Ангарская — Angarskaya Ulitsa).

Depending on its position, the letter $\Gamma$ in Russian can convey several different sounds. The first is the aforementioned hard consonant $[\mathrm{g}]$. The second is the reduced sound [k] that is achieved through regressive assimilation or devocalization at the end of the word. However, this reduction is purely phonetic and isn't mirrored in writing. Both $[\mathrm{g}]$ and $[\mathrm{k}]$ can also be palatalized as $\left[\mathrm{g}^{\mathrm{j}}\right]$ and $\left[\mathrm{k}^{\mathrm{j}}\right]$, reflecting such palatalization in transliterated variants would be impractical due to its minimal (and only approximated) presence in English.

As such, a close parallel for the Russian $\Gamma$ positioned in front of the mid and back vowels [o], [u], [a], would be the English $G$. Compare the following:

Улища Габричевского - Gabrichevskogo Ulitsa

Улица Ангарская - Angarskaya Ulitsa

Улица Городская - Gorodskaya Ulitsa

Улица Беговая - Begovaya Ulitsa

Улицуа Губкина - Gubkina Ulitsa

Улийа Богучарская - Bogucharskaya Ulitsa

Consider the next scenario, where the Russian $\Gamma$ is situated before the front vowels [i], [e], and central vowel [i]. The situation is complicated by the rules of pronunciation of $G$ before letters $E, Y, I$ in 
English, namely because, with some exceptions, $G$ is then pronounced as an affricate consonant [d] (e.g., general - ['dzenərəl], ginger - ['d子Indzə], and so on). Among the exceptions to this principle are words of general Germanic origin (such as gird that originates from Old Germanic *gurdjan and takes the form gyrdan in Old English while maintaining the pronunciation of the initial $G$ as $[\mathrm{g}]$ under the influence of the Old Saxon gurdian); as well as given names of Scottish and Hebrew origin (consider Gideon, Gilead, Giorsal, etc.) (Oxford English Dictionary). But according to the Dictionary of the British Spelling, exceptions to the main rule of pronouncing $G$ constitute only $1 \%$ of total cases, and the presence of a front vowel immediately after $G$ is a strong indicator of the sound [d3] (Brooks, 2015).

As such, conveying the hard Russian sound [g] with an English letter $G$ in positions before the vowels $И[\mathrm{i}], Э$ [e], $Ы[$ [i] (which, according to the UN Technical Reference manual and other common transliteration systems, are represented by letters $I, \grave{E}$, and $Y$ respectively) represents a risk that the text's recipient will read the letter $G$ according to the rules of English, i.e. as the affricate [dz]. This results in an inaccurate representation of the word and hinders the act of communication, for instance: улица ЕгерскаяEgerskaya Ulitsa (*['cdzərskayə]), улища Зоологическая - Zoologicheskaya Ulitsa (*[zaalə’dzitfskayə])

A different way to represent the sound [g] before front vowels in English is by employing a digraph $G H$ that corresponds to the sound $[\mathrm{g}]$ in the beginning and in the middle of some words. Some of the examples in which $G H$ represents the sound [g] include ghillie, gherkin, and so on, as well as words borrowed from foreign languages: spaghetti, ghetto, narghile. The fact that $[\mathrm{g}]$ in borrowed words is represented with $G H$ attests that the usage of this digraph in a bilingual toponymic context reduces the risk of erroneous pronunciation of $G H$ as [dz] or [f] (like in tougher, sloughing, etc.). The following Moscow street names exemplify the usage of $G H$ to convey the names of city toponymy:

Улича Ибрагимова - Ibraghimova Ulitsa

Улица Косыгина - Kosighina Ulitsa

Улица Селигерская - Seligherskaya Ulitsa

Улица Энергетическая - Energheticheskaya Ulitsa

Lastly, the third instance of $G$ is in a position before a consonant. The rules of the English language dictate that $G$ in front of consonants is pronounced as [g] (except for the combination $g n$ at the beginning of 
a word, e.g. gnu, gnome; as well as some borrowings from French, such as sovereignty, mignon, chignon, etc.; and a number of words featuring the combination $g m$ that originate from the ancient Greek and came into English through Latin, e.g. syntagm, epiphragm, etc.). Consequently, the possibility of erroneous pronunciation in most of these cases is significantly lower. Consider Fig. 1, Fig. 2 for examples of the object names from city landscape.

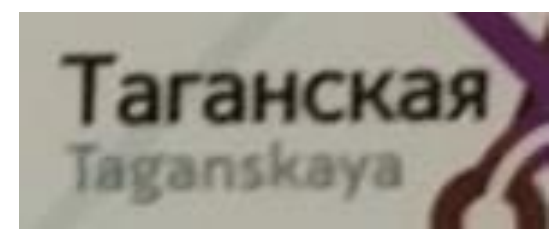

Figure 1. Таганская - Taganskaya

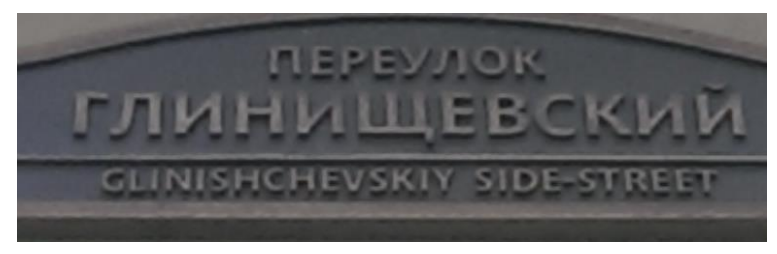

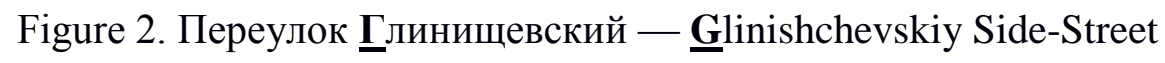

The same principle applies to $G$ situated at the end of Russian toponyms. Since the digraph $G H$ at the end of a word in English signifies the sound [f] (tough, sough, etc.) or a lack of sound (bough, nigh, etc.), its usage at the end of Russian generic names conveyed by the means of practical transcription is not advisory. To add to that, the practical necessity of using $G H$ at the end of words in the process of transcription or transliteration is low, as the analysis of the up-to-date corpus of street names in Moscow and Saint Petersburg demonstrated that there were no occurrences of the pair $\Gamma X$ at the end of any street names in these two cities, and such a combination is generally rare in Russian. Examples of street names ending with $\Gamma$ include: улица Кашёнкин Луг - Kashonkin Lug Ulitsa, улища Балчуг - Balchug Ulitsa.

As a result, there are several ways to convey the Russian letter $\Gamma$ depending on the position it takes in a word and the surround sounds. See the summary in section 4.0, Table 1.

\subsection{Romanization of Russian E as E}

When considering a way to represent the Russian letter $E$, it is imperative to look at the position it takes in a given word. Similar to $\Gamma$ above, depending on its placement, the Russian $E$ can correspond to a 
number of sounds. The letter $E$ in Russian represents a combination of the palatal approximant [j] with the subsequent $[\mathrm{e}]$ in these cases:

- When it is situated at the beginning of a word.

- When it follows a vowel.

- When it follows a hard (Ъ) or soft (b) separation sign.

In any other position, the letter $E$ corresponds to a single sound [e]. It should be noted that $E$ palatalizes the preceding hard consonant (e.g., небо [njebo]), but this change in pronunciation is not taken into account in the scope of this article for the purposes of a written practical transcription system.

The UN's Technical Reference manual suggests the Latin letter $E$ as an equivalent of the Russian $E$ regardless of its position. This approach produces reliable results when the Russian $E$ denotes a single sound [e]. In the three aforementioned cases where $E$ corresponds to the sound combination [je], additional indication is desirable. Tradition of practical transcription currently employed in Russian metropolises (Moscow, Saint Petersburg) demonstrates that whenever a name starts with $E$, two approaches are used to convey it by the means of the Latin alphabet: either a single $E$ or a digraph $Y E$. See the following examples: Универсальный спортивный комплекс «Есенинский» - Universal Sports Complex «Eseninsky»; Елизаровская - Yelizarovskaya.

It is worth noting that when a Russian word starts with $E$, its representation with a single Latin letter $E$ could lead to a possible confusion with names that start with the letter $Э$ (that also conveys a single sound [e]). Analysis of the names of geographical objects and streets in Moscow and Saint Petersburg shows that there are possible overlaps between homophonic names that begin with either $E$ or $Э$. One such example is the street Ереванская in Moscow and Эриванская in Saint Petersburg. While they exhibit a difference in spelling, they turn into homophones when transliterated by using the Russian $E$-> Latin $E$ equivalent: Erevanskaya (Ереванская) - Erivanskaya (Эриванская). In such circumstances the two-letter representation $Y E$ is more reliable for the purpose of avoiding possible errors in oral communication, for instance when a foreign tourist asks a local person for directions. But given the geographical distance between these two streets, and also the general lack of geographic names that are only distinguishable by a single letter difference, it is reasonable to assume that the usage of $Y E$ is superfluous. 
When $E$ follows a vowel (e.g., улица Волочаевская), several methods can be used to reflect the resulting sound [je]. Examples found on the city maps of Moscow include such options as Volochaevskaya, Volochayevskaya, and Volochajevskaya. Since the combination of $A E$ (and, similarly, IE, $O E$ ) can be perceived as long vowels [a:], [i:], or [o:] with a silent [e], it is possible to indicate the presence of the palatal approximant [j]. Of the two options, both $Y E$ and $J E$ have a similar presence in navigational texts and were correctly deciphered by an equal number of respondents who were asked to read such street names aloud (Zots, 2016).

When $E$ follows a separation sign (е.g., улииа Загорьевская), it is important to consider that some Russian streets sound similar to each other, with a separation sign making a noticeable distinction, for ехатple улища Васильевская - улища Маршала Василевского (with the word Маршала being attributed to several different streets named after various Russian marshals and thus often omitted in casual speech). In this case, an indication of [je] becomes even more important and should not be neglected. Both options Zagorjevskaya and Zagoryevskaya can be found on city signs, and the final decision should be made in consideration of the rest of the transliteration system, so that not to overuse either $J$ or $Y$ in digraphs corresponding to other sounds and letters.

\subsection{Romanization of Russian $\ddot{E}$ as $\ddot{E}$}

When it comes to $\ddot{E}$, the same principles largely apply as with $E$, since the two letters are similar in their pronunciation. and both consist of a palatal approximant [j] and a following vowel sound. However, another thing of note is the two dots above the letter that are outwardly similar to an umlaut in German, diaeresis in French, or diacritics in general, as present and recognizable in numerous world languages. While the double dots are not officially considered a diacritic in the Russian linguistic tradition, they are often confused with one by non-linguists.

This raises an important point — due to the fact that letters with diacritics are absent from the Latin alphabet, they (and, by association, the letter $\ddot{E}$ ) can present a challenge to people whose mother tongue or primary language of communication is English. It could be seen as an advantage for a practical transcription system to only include such symbols that are present in the target language — in this case, English. Some recent examples of stepping away from diacritics in a modern day include the alternative transliteration 
system (so called System B) in GOST 7.79-2000 and the recent transition of the Kazakh language from the original Kazakh alphabet based on the Cyrillic graphic to Latin (Nazarbaev, 2017).

Instead of using double dots in a transliterated word, it is possible to convey $\ddot{E}$ and other vowels with a palatal approximant [j] by using a digraph. There have been examples of using such an approach in older systems (Uniform System of Russian Transliteration 1890). There are several traditional methods to transcribe [j], namely with the help of consonants $Y, J, I$, and currently the choice of a letter varies from map to map, with no particular variant being dominant (compare Филёвский парк — Filyovsky Park/Filiovsky

\section{Park/Filjovsky Park).}

\subsection{Romanization of Russian $\nVdash$ as $\check{Z}$}

The current tradition of conveying the letter $\mathscr{K}$ in toponymy of surveyed Russian cities (including Moscow and Saint Petersburg) is twofold, with variants $Z H$ and $J$ equally represented in street names, metro stations, and titles of objects of urban infrastructure. Consider Fig. 3 and 4 for examples of names documented on the metro maps and street signs of the aforementioned cities.

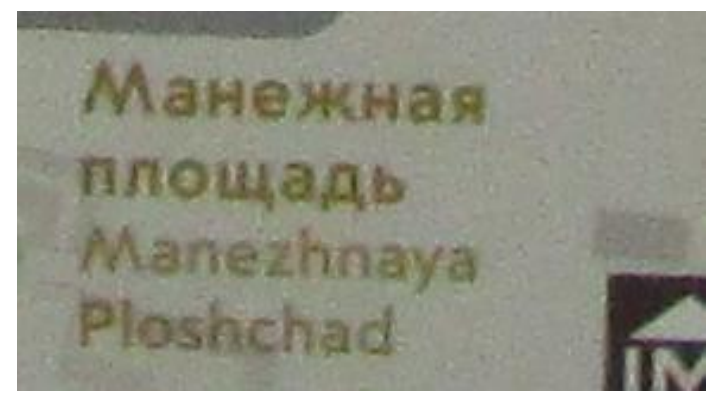

Figure 3. Мане్ная площадь — Manezhnaya Ploshchad

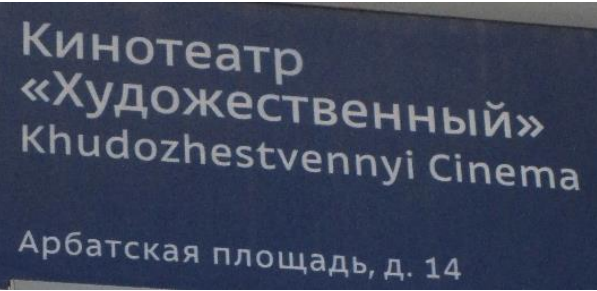

Figure 4. Кинотеатр «Художественный» — Khudozhestvennyi Cinema

More examples include:

Калужсская - Kaluzhskaya (Moscow metro station — a map in a station hall)

Жулебино - Julebino (Moscow metro station — official map)

Межндународная - Mejdunarodnaya (Moscow metro station — official map) 
Улиияа Торжковская - Torzhkovskaya Street (Saint-Petersburg street)

Волюсккая улиия - Volzhskaya Street (Sevastopol street)

There were no documented examples of $\mathcal{W}$ as $\check{Z}$ on street signs, metro station names, and tourist maps of the analyzed city texts. Both $Z H$ and $J$ have advantages and drawbacks associated with them in the context of city navigation. Let us consider how these letters and their corresponding sounds are represented in English.

The Dictionary of the British English Spelling System gives the following phonemic correlations for the grapheme $J:[d],[j],[3],[h]$, with the sound [d] constituting almost $100 \%$ of usage cases. The other three sounds are characteristic of borrowed words and are present in a much lesser extent (Brooks 2015).

At the same time, there's a special note accompanying the grapheme $Z H$ : 'The spelling <zh> is also used to represent / $/$, but $<\ldots>$ it occurs only in transcriptions of Russian names, e.g. Zhivago, Zhores,' which signifies that the grapheme is familiar to native English speakers as a sign of Russian names and titles.

In the Russian language, letter $\mathscr{K}$ represents the sound [z], which is similar to [3] in European languages, but has a harder quality to it. Considering that and the fact that $J$ mainly corresponds to [d]], it is recommended to use the grapheme $Z H$ to represent the Russian letter $\mathscr{K}$.

\subsection{Romanization of Russian $Y$ as $\check{C}$}

Russian $Y$ is traditionally conveyed as $C H$, as witnessed in such transliteration systems as GOST 7.79-2000 (System B), ALA-LC, BGN/PCGN, and others. This practice is confirmed by examples of street signs in Moscow and Saint Petersburg. Consider Fig. 5 and 6.

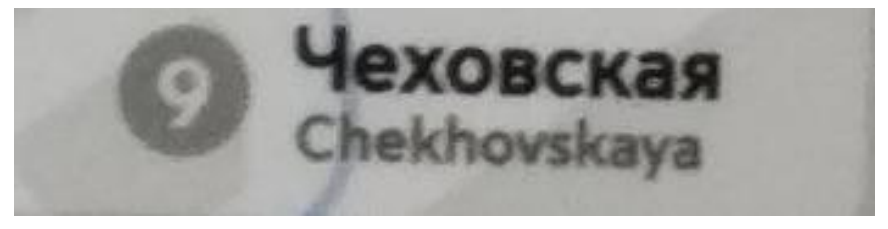

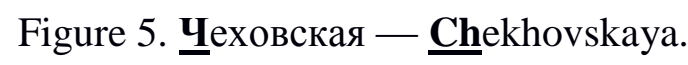

2-й ЗАЧАТЬЕВСКИЙ переулок

2-nd ZACHATYEVSKIY side-street

Figure 6. 2-й Зачатьевский переулок $-2^{\text {nd }}$ Zachat'yevskiy side-street 
As with $\check{Z}$ above, the usage of $\check{C}$ comes with the disadvantage of not being represented in the Latin alphabet. In a user-oriented system that isn't solely intended for professional linguists, we believe $\mathrm{CH}$ to be a more intuitive option to pronounce correctly.

\subsection{Romanization of Russian $W$ as $\check{S}$}

Russian $W$ is traditionally conveyed as $S H$, as witnessed in the majority of current transliteration systems, including GOST 7.79-2000 (System B), ALA-LC, BGN/PCGN, and others. Consider the examples of Moscow street and metro signs on Fig. 7 and 8.

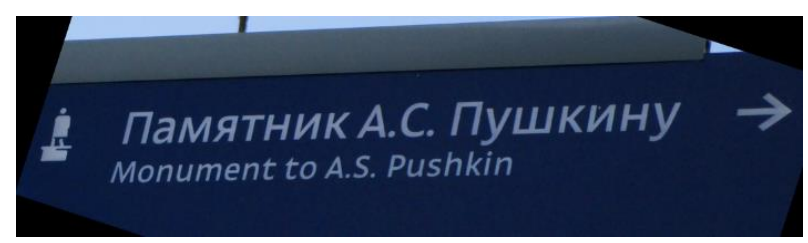

Figure 7. Памятник А.C. Пушкину — Monument to A.S. Pushkin.

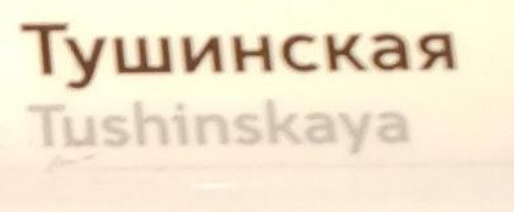

Figure 8. Тущинская — Tushinskaya.

The variant $S H$ without a diacritic helps to correlate the pronunciation of the station/street name with its written variant and avoid possible misunderstanding and confusion of $\check{S}$ with $S$ for individuals without prior linguistic training. Other Moscow street names containing $U$ and their possible transliterations include:

Улица Маршала Катукова - Marshala Katukova Ulitsa

Улица Башиловская - Bashilovskaya Ulitsa

Улища Воздушная - Vozdushnaya Ulitsa

\subsection{Romanization of Russian $Щ$ as $\check{S} \check{C}$}

Aside from using diacritics to convey a letter, the example of $Щ$ as $\check{S} \check{C}$ also introduces ambiguity in the UN Technical Reference, since it can be interpreted both as a single letter $Щ$ and as a pair of consecutive letters $\amalg \Psi$. Cases of consecutive $\amalg \Psi$ are rare in Russian geographical names, and there are no streets in 
Moscow or Saint Petersburg that include this combination, but there are other historical geographical places that contain them, such as Дуб черешчатыц, a natural monument in Kaliningradskaya Oblast.

The current tradition of city navigation texts does not reflect the recommendation to use $\check{S} \check{C}$ for $Щ$. Instead, examples on Fig. 9, 10, 11, and 12 have been documented.

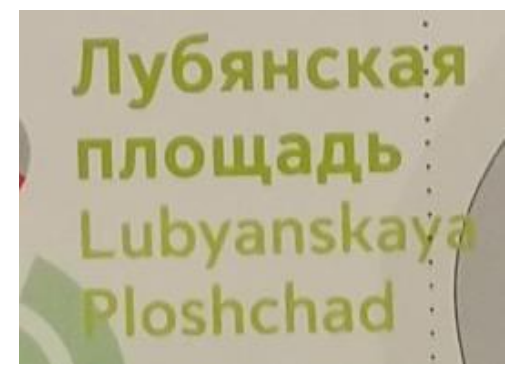

Figure 9. Лубянская площадь — Lubyanskaya Ploshchad.

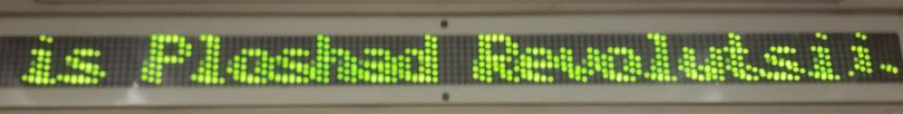

Figure 10. Ploshad Revolutsii (for the Russian metro station Площадь Революции, Mоscow).
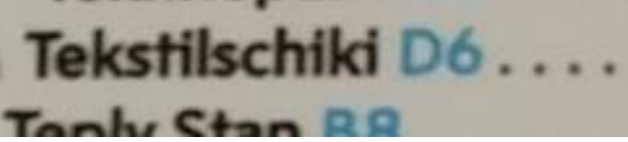

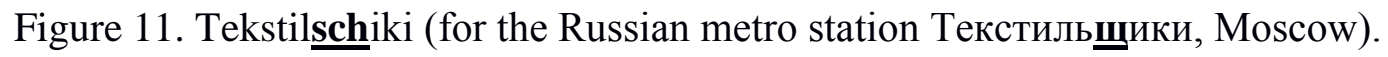

\section{Schukinskaya}

Figure 12. Schukinskaya (for the Russian metro station Щукинская, Moscow).

Note that the common variants of transliteration on the figures above include $\mathrm{SHCH}, \mathrm{SCH}$, and $\mathrm{SH}$. Another variant, $S H H$, is proposed in GOST 7-79-2000. For the purposes of tourist-oriented city navigation we propose $S C H$ as a shorter and less ambiguous option. All the variants where $S$ precedes $H$ increase the risk of reading this combination of sounds as [sx], while $S C H$ is more explicitly understood as [ $\left[\mathrm{t}_{6}\right]$ or [66]. Besides, the variant $S C H$ maintains overwhelming presence on the analyzed maps and other navigational messages, as indicated by collected evidence.

3.8 Romanization of Russian $\mathrm{b}$ and $\mathrm{b}$ as " and 'respectively 
While representation of the hard and soft sign as quotation marks is unambiguous, it rarely tells the reader how a given word should be pronounced. As a result, native readers without special knowledge or linguistic background often ignore the quotation marks entirely. A short survey among native English speakers conducted on an international web-forum reddit.com showed that, when asked to pronounce the street name Vasil'evskaya (a transliteration of the Russian name Васильевская), 25\% of the 109 respondents did not articulate the quotation mark in any way, while the majority (47\%) made a short pause after the letter $L$, which amounts to distinct pronunciation of two separate words (Vasil Evskaya) (Zots, 2016). This leads us to believe that English speakers without prior linguistic training are not able to correctly determine the meaning of a quotation mark in a given context.

While examples of $b$ and $b$ represented as quotation marks can be found on street signs of Moscow and Saint Petersburg, most of the time they are encountered on older signs and tablets. In the majority of cases, these two letters are either not reflected in transliteration or transliterated by different means. Consider Fig. 13, 14, 15, and 16 .

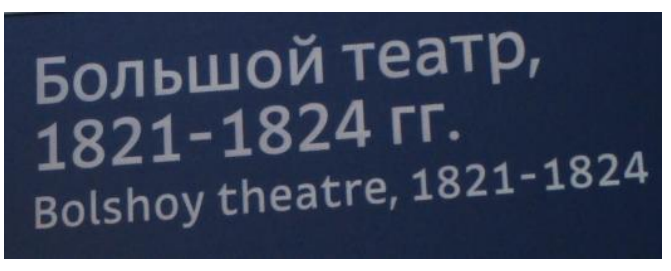

Figure 13. Большшой театр — Bolshoy theatre.

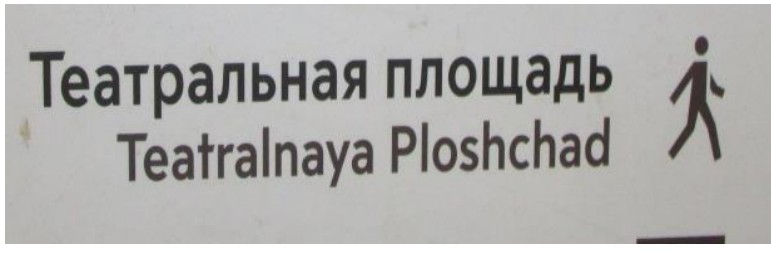

Figure 14. Театральнная площадь - Teatralnaya Ploshchad.

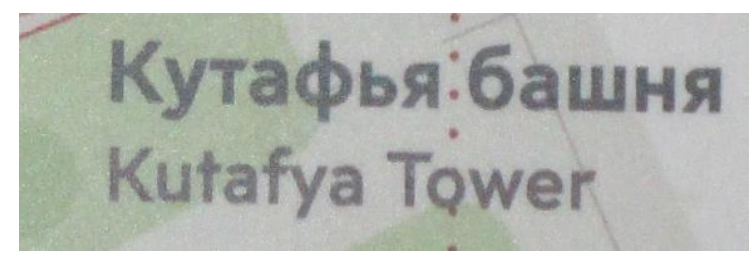

Figure 15. Кутафц् я башня - Kutafya Tower. 


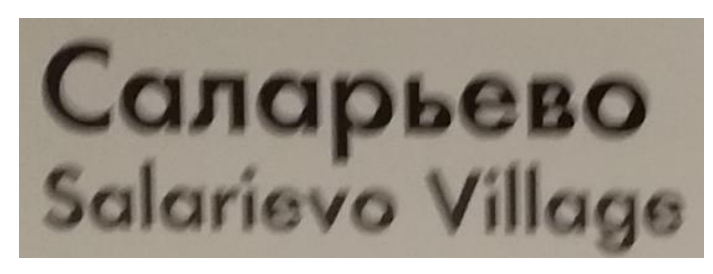

Figure 16. Саларьево - Salarievo Village.

\subsection{Romanization of Russian Э as $\grave{E}$}

Transliteration of $Э$ as $\grave{E}$ is another example of using a diacritic to convey a letter. Most of the established systems of transliteration (GOST 7.79-2000 (System B), ALA-LC, BGN/PCGN, ICAO, BS 2979:1958, etc.) don't differentiate between $Э$ and $E$, and there are no street names in the analyzed material that could be confused with each other by replacing $\ni$ with $E$ or vice versa. Given that, for the purpose of a city-oriented transliteration system the variant $E$ is the least ambiguous.

\subsection{Discussion}

The conducted research demonstrates that the currently employed international transliteration practices for the Russian language are not sufficiently capable of forming a bilingual locus of a navigational landscape. Considering the mode of communication between the foreign tourists and native speakers, i.e. a short-term integration of foreigners into an unknown environment, cross-cultural communication takes form of an interpersonal contact, over the course of which a foreign visitor sends a message to the native Russian speaker by reading the Romanized information on a map or a sign. The ability to read the Romanized message, as well as the transliterated/transcribed text's resemblance to the sound of the original Russian message is crucial to achieve mutual understanding. The conclusions drawn upon each individual letter and its spoken representation are based first and foremost on this hypothetic social situation. As such, Romanization itself is understood as a process of combining the means of transliteration, transcription, and translation that considers the phonetic and alphabetic composition of a word and builds upon the practices of transliteration that are present in written documents and messages around a given city. This approach allows a researcher to utilize the experience of transliteration accumulated in a particular locale and further modify the resulted text to fit the needs of a concrete social group.

The critical analysis of phonological properties of Russian street names shows that neither the current tradition of their Romanization as presented on the street signs, nor the suggestions offered in the UN 
Technical Reference (and other similar transliteration systems, like GOST 16876-71, GOST 7.79-2000, etc., that follow the same approach) are fully suitable to ensure secure passage through Russian cities without knowledge of either the Russian language or, at the minimum, the Cyrillic alphabet. It is therefore practical to distance such Romanization methods from their scientific origins (that were first introduced to serve the needs of bibliographers and librarians) and instead concentrate on the practical needs of the general population and, primarily, non-linguists. The suggestions set forward in the section 3.0 are summed up in the following table:

\begin{tabular}{|c|c|c|}
\hline [66] & \multicolumn{2}{|c|}{ Sch } \\
\hline$[\mathrm{x}]$ & $\begin{array}{c}\text { Kh } \\
\text { - at the end of a word } \\
\text { - before a vowel }\end{array}$ & $\begin{array}{c}\mathrm{H} \\
\text { - at the beginning of a } \\
\text { word } \\
\text { - before a consonant }\end{array}$ \\
\hline [ja], [jæ] & $\begin{array}{c}\text { Ya } \\
\text { - at the beginning of a } \\
\text { word } \\
\text { - after a vowel }\end{array}$ & $\begin{array}{c}\text { Ja } \\
\text { - after a consonant }\end{array}$ \\
\hline [jo] & Jo & $\begin{array}{c}\mathrm{O} \\
- \text { after sibilants } \\
\end{array}$ \\
\hline$[\mathrm{ju}],[\mathrm{ju}]$ & $\begin{array}{c}\mathrm{Yu} \\
\text { - at the beginning of a } \\
\text { word }\end{array}$ & $\begin{array}{c}\mathrm{U} \\
\text { - after a consonant } \\
\text { - after a separation } \\
\text { sign }\end{array}$ \\
\hline$[\mathrm{je}],[\mathrm{j} \varepsilon]$ & $\begin{array}{c}\text { Je } \\
\text { - after a separation } \\
\text { sign }\end{array}$ & $\begin{array}{c}\mathrm{E} \\
\text { - at the beginning of a } \\
\text { word } \\
\text { - after a vowel }\end{array}$ \\
\hline [g] & $\begin{array}{c}\mathrm{G} \\
\text { - at the end of a word } \\
\text { - before vowels }[\mathrm{a}], \\
{[\mathrm{o}],[\mathrm{u}]}\end{array}$ & $\begin{array}{c}\text { Gh } \\
\text { - before vowels }[\mathrm{i}] \text {, } \\
{[\mathrm{i}],[\mathrm{e}]}\end{array}$ \\
\hline [i] & & \\
\hline
\end{tabular}

Table 1. Romanization of certain complex Russian sounds

\subsection{Conclusions}

In conclusion, for the Technical Reference system to be usable in an everyday environment by nonspecialists, it has to be adapted in consideration of already employed practices. The resulting system of practical transliteration should take into account its potential user base (specialists vs non-specialists in the 
science of language), the area of application (current navigational messages intended to appeal to mass audience or narrower use cases like specialized maps with reversibility in mind), and should consider every name on an individual basis, with the final decision delegated to the translator or translation committee working on a specific task.

The critical analysis of currently established practices and phonetic peculiarities of street names examined in this paper helps to identify some of the inconsistencies between the UN Technical Reference manual and other widely used transliteration systems and their practical everyday application. The conclusions drawn in the paper regarding each analyzed letter help to make a projection about the possible variants of Romanization of Cyrillic for the future application. Suggestions outlined in the paper can be extrapolated for use with new navigational messages in various cities of Russian Federation. Following the results of the presented research, it is possible to process any volume of city texts through the method of iterative filtration described in section 2.0. Further research of boundaries between languages in a translingual environment and their interaction are necessary to offer insights into linguistic, national, and cultural identity of a given city landscape.

\section{Reference List}

Androutsopoulos, J. (2012). "Greeklish": Transliteration practice and discourse in the context of computermediated digraphia. Orthography as Social Action, 359-392.

\section{https://doi.org/10.1515/9781614511038.359}

Bondar, A., Glukhov, A., \& Goncharova, М. (2013). Концепция единой системы навигации города Москвы [Concept of Common Navigation System in Moscow]. Retrieved from https://docplayer.ru/26649170-Koncepciya-edinoy-sistemy-navigacii-goroda-moskvy.html

Brooks, G. (2015). Dictionary of the British English Spelling System [Open Book Publishers version]. $\underline{\text { http://dx.doi.org/10.11647/OBP.0053 }}$

Ethnologue: Languages of the World. (2019). Retrieved from https://www.ethnologue.com/language/eng.

Groves, C. (1890). Systems of "Russian Transliteration.” Nature, 41, 534-535. 
International Phonetic Association. IPA Chart with Sounds. (2015). Retrieved from

\section{https://www.internationalphoneticassociation.org/content/full-ipa-chart}

Interstate Council for Standardization, Metrology and Certification. (2002). ГОСТ 7.79 - 2000. Система стандартов по информации, библиотечному и издательскому делу. Правила транслитерации кирилловского письма латинским алфавитом [GOST 7.79-2000. System of Standards for Information on Library Science and Publishing. Rules of Latinization of Cyrillic Script]. Moscow, Russia: Издательство стандартов.

Ivanov, L. (2017). Streamlined Romanization of Russian Cyrillic. Contrastive Linguistics, 42, 66-73. https://www.researchgate.net/publication/318402098_Streamlined_Romanization_of_Russian_Cyrill ic

Kirilina, А. (2013). Описание лингвистического ландшафта как новый метод исследования языка в эпоху глобализации [Description of Linguistic Landscape as a New Method of Language Research in Globalization Era]. Вестник ТвГУ, 24, 159-167.

Moscow Mayor official website. Единая система транспортной навигации в Москве [Single System of Transport Navigation in Moscow]. Retrieved from https://www.mos.ru/city/projects/design/

Nazarbaev, N. (2017). Указ «О переводе алфавита казахского языка с кириллицы на латинскую графику» [Decree “On Transition of Kazakh Alphabet from Cyrillic to Latin Script”]. Retrieved from http://www.akorda.kz/ru/legal_acts/decrees/o-perevode-alfavita-kazahskogo-yazyka-s-kirillicy$\underline{\text { na-latinskuyu-grafiku }}$

Oxford English Dictionary. "gird, v.” OED Online. Oxford University Press. Retrieved from https://www.oed.com/viewdictionaryentry/Entry/78456

Peshkova, N. (2016). Исследование городского лингвистического ландшафта как способ межкультурного взаимодействия в полиэтническом социуме [Research of Linguistic City Landscape as Means of Cross-Cultural Interaction in Polyethnic Society]. Bonpocbl психолингвистики, 29, 229-240. 
Presidential Library. (2018). В Президентской библиотеке представят первую англо-русскую топонимическую энциклопедию [First English-Russian Toponymic Encyclopedia to be Presented in the Presidential Library]. Retrieved from https://www.prlib.ru/afisha/706906

Rivlina, A. (2016). Global English-related digraphia and Roman-Cyrillic biscriptial practices. Procedia Social and Behavioral Sciences, 14, 207-212. https://doi.org/10.1016/j.sbspro.2016.12.006

Souleimanova, O., \& Kholodova, D. (2014). 3T in Linguistic Navigation through Megapolis - Translation, Transcription, Transliteration. In Translation Studies and Translation Practice: Proceedings of the 2nd International TRANSLATA Conference (pp. 217-222). Innsbruck: University of Innsbruck. https://doi.org/10.3726/b10843

Souleimanova, O., \& Zots I. (2019). Проблемные «зоны» современной урбанистики в глобальном пространстве: транслитерация урбанонимов [Problematic “Zones” of Modern Urbanistics in Global Space: Transliteration of Urbanonyms]. Вопросы ономастики. 4, 134-151. doi:10.15826/vopr_onom.2019.16.4.049

Uniform System of Russian Transliteration. (1890). Nature, 41, 396-397. https://doi.org/10.1038/041396a0

United Nations Group of Experts on Geographical Names. (2007). Technical Reference Manual for Standardization of Geographical Names. The United Nations. Retrieved from https://unstats.un.org/unsd/geoinfo/UNGEGN/wg5.html

USSR State Committee on Standards. (1981). ГОСТ 16876-71. Правила транслитерации букв кирилловского алфавита буквами латинского алфавита [GOST 16876-71. Transliteration of Russian Words by Latin Characters]. Moscow, Russia: Издательство стандартов.

Vikulova, L. (2014). Городское пространство как новая коммуникативная среда эпохи глобализации [City Landscape as New Communication Environment in Globalization Era]. In Языковая политика и языковые конфликты в современном мире: Межд. конф.; Доклады и сообщения; ИЯ РАН, НИЦ по национально-языковым отношениям (рр. 302-309). Moscow, Russia: ТЕЗАУРУСЯзыки народов мира. 
Zamyatin, D. (2006). Культура и пространство: моделирование географических образов [Culture and Space: Modelling of Geographical Images]. Moscow, Russia. Знак.

Zots. (2016). Роль латинизации в формировании текстов городского ландшафта [Role of Latinization in Producing City Landscape Messages]. In Грамматические категории в контрастивном аспекте: Сборник научных статей по материалам международной конференщии (рр. 181-186).

Moscow, Russia: Московский государственный педагогический университет. 